\title{
Effects of Transaction Costs on Mushroom Producers' Choice of Marketing Channels: Implications for ACCESS TO Agricultural Markets in Swaziland
}

\author{
Majola L Mabuza, Gerald Ortmann and Edilegnaw Wale \\ School of Agricultural, Earth and Environmental Sciences, University of KwaZulu-Natal
}

Accepted: July 2013

\begin{abstract}
Mushrooms are highly perishable agricultural commodities, and as such their marketing is invariably associated with high transaction costs. Despite the mushroom enterprise gaining popularity in a number of sub-Saharan African (SSA) countries, where production is dominated by rural-based small-scale farmers, no research has been done to study the nature and complexity of transaction costs encountered by these producers in attempting to participate in mainstream supply chains. This study uses cross-section data obtained in 2011/2012 from mushroom producers in Swaziland to study the effects of transaction costs on producers' choice of marketing channels and the quantity of mushrooms supplied. Having used Cragg's model for analysis, the results indicate that producers' decisions of where to sell their mushrooms are significantly affected by household labour endowment, production capacity, access to cooling facilities and market information, and producers' bargaining position. Meanwhile, the quantities of mushrooms sold are significantly influenced by the difficulty in accessing reliable transport and producers' level of uncertainty in meeting buyers' quality requirements. The study concludes by highlighting potential interventions that could minimise marketing and transaction costs and further improve the general agricultural marketing environment in Swaziland.
\end{abstract}

Key words: mushrooms, marketing channels, transaction costs, Swaziland

JEL: Q13

1

\section{Background}

Oyster mushroom production was officially introduced in Swaziland through a United Nations Development Programme (UNDP)funded initiative in 2001 with an intention to assist rural-based small-scale farmers to diversify and improve their financial independence and livelihoods. Preference for mushrooms, particularly the oyster, over other prospective enterprises was mainly influenced by the abundance of production inputs in Swaziland (e.g. substrate materials ${ }^{1}$ ), their ease of production, suitability in diverse agro-ecological zones, and their relatively high nutritional and medicinal qualities (Chang \& Miles, 2004). However, it is important to note that producers can only realise significant benefits from their ventures if they operate within a commercialised setting, a choice that farmers will make if markets provide incentives to increase production and enhance household income generation prospects (Delgado, 1999). Worth noting as well, is that market participation is not costless as attempts to commercialise smallholder agriculture in Africa have not yielded the expected results primarily due to lack of proper institutions and infrastructure (Fafchamps, 2004). These challenges often result in increased marketing and transaction costs, which underlie the failure by farmers to meet market demands for quality, quantity and timeliness (Karaan, 1999). The concept of transaction costs was enunciated by Coase (1937), who defined them as costs incurred in the process of carrying out any exchange. Transaction costs are incurred before (ex ante) and after (ex post) the actual exchange and are broadly conceptualised as the tangible and intangible costs of searching for a partner with whom to exchange a product, screening potential trading partners to ascertain their credibility, bargaining with potential trading 
partners to reach an agreement, transferring the product, monitoring the agreement to ensure that its conditions are fulfilled, and enforcing the exchange agreement (Jaffee, 1995).

Before deciding which marketing channel to use, producers normally have to make a preliminary decision of whether or not to sell, which generally depends on the availability of marketable surplus (Goetz, 1992). Once the producer decides to participate in the output market, he/she makes a choice between selling at the farm gate, through intermediaries or transporting the product to the nearest lucrative market. Mushrooms are highly perishable commodities, and as such their marketing is invariably associated with high transaction costs, which if not contained may ultimately affect producers' competitiveness in the value chain or perhaps increase to a level where markets may be adjudged to be 'missing' (de Janvry et al., 1991). As opposed to other food commodities that have a longer shelf life (e.g. grains), mushrooms require rapid and refrigerated transportation to consumption centres or immediate processing into less perishable forms. This limits the period of time during which mushrooms can be marketed as a fresh commodity or used as raw material in processing. Such conditions normally subject producers to limited marketing flexibility as they often find themselves in an unfavourable bargaining position, particularly against buyers who have alternative sources of supply (Jaffee, 1995).

Despite the difficulty of measuring transaction costs, some attempts have been made previously to study their influence on the choice of marketing channels for African producers of various agricultural commodities such as beef (Shiimi et al., 2012), bananas (Woldie \& Nuppenau, 2011; Jagwe \& Machete, 2011) and coffee (Fafchamps \& Hill, 2005), among others. Nonetheless, no attention has been accorded to study the marketing of non-conventional HighValue Agricultural Commodities (HVACs) like mushrooms, a gap that this study attempts to address. Typical of HVACs, which are generally known for having a relatively high income elasticity of demand (Kumar et al., 2011), cultivated mushrooms are largely consumed by the urban working class and people with special diet preferences. These consumers purchase mushrooms from a number of selling points, including supermarket chain stores, whose procurement policies provide an opportunity for small-scale farmers to participate in mainstream markets, enabling them to generate substantial returns (Emongor \& Kirsten, 2009).

The importance of cultivated mushrooms emanates from various dimensions. For instance, the production procedure qualifies the enterprise as an environmentally unique process for bioconversion of non-edible plant biomass to generate value-added products which are highly nutritious, tasty and relatively quick and easy to prepare. In contrast to other HVACs (e.g. vegetables), cultivated mushrooms contain all essential amino acids, have relatively high levels of vitamins, fibre and inorganic mineral nutrients (Chang \& Miles, 2004). More importantly, they are effective in enhancing the human body's defence against various types of cancers, viral infections (including HIV), diabetes, constipation and cardiovascular diseases (Roupas et al., 2012). As a result of such attributes, a number of SSA countries have since the early 2000s included the mushroom enterprise in their agricultural systems (see Zero Emissions Research Initiative (ZERI), 2005). Therefore, in attempting to improve the benefits associated with the enterprise, it is important to identify possible means of reducing transaction costs which are often considered an embodiment of barriers to market participation by resource-poor producers (Key et al., 2000). Reducing transaction costs is likely to increase linkages between actors in the mushroom value chain and improve producers' market access and household income. Given the paucity of empirical studies of this nature in Swaziland, the results will inform the formulation of pragmatic policy interventions that could improve the general agricultural marketing environment, which constitutes an indispensable element in the advancement of Swaziland's agricultural development programme (see Food and Agricultural Organisation (FAO), 2011). The rest of the paper is structured as follows: section 2 outlines the methodology, which constitutes the conceptual framework, empirical model, and data collection procedures. Section 3 discusses empirical results, while section 4 concludes the study with policy recommendations. 
2

Methodology

\subsection{Conceptual framework}

In deciding where to sell a particular commodity, producers base their decisions not only on the price they expect to receive, but also on additional costs related to transacting in available markets (Jaffee, 1995). Considering that transaction costs alone could be a major barrier to market participation, farmers are more likely to choose to supply their commodities through a channel that has less transaction costs in their quest to maximise profit (Key et al., 2000). However, transaction costs have a large unobservable component; hence, they are difficult to quantify. This has unsurprisingly resulted in the dearth of literature on the direct measurement of exchange-related costs, particularly in the area of agricultural marketing (Hobbs \& Kerr, 1999). Where attempts have been made previously, researchers (e.g. GabreMadhin, 2001; Royer, 2011) have based their estimation on the opportunity costs of alternatives, which are also not easily identifiable or quantifiable. As such, aspects like market information search and bargaining procedures are rarely included in most studies and are unlikely to be comprehensive when included. Despite Collins and Fabozzi's (1991) contention that no one approach of conceptualising and estimating transaction costs is best in all circumstances, in attempting to address the above-indicated inherent challenges, this study borrows from the framework postulated by Vakis et al. (2003) which provides a dependable setting for studying producers' channel choices and quantity supplied as a function of commodity prices and two broad categories of proportional and fixed transaction costs.

Following Vakis et al. (2003), if there exist $j$ available markets where a certain quantity of mushrooms $q_{i}$ can possibly be sold, the producer's marketing strategy is conceptualised to be influenced by a number of factors. Firstly, selling in market $j$ for a given transaction $i$ could be associated with proportional transaction costs $T C_{i j}^{p}$ which may arise due to various factors including the distance $d_{i j}$ and time $m_{i j}$ to reach market $j_{i}$, and other individual-specific characteristics $z_{i j}^{p}$ such as the difficulty to access transport. This can be expressed as:

$$
T C_{i j}^{p}=T C^{p}\left(d_{i j}, m_{i j}, z_{i j}^{p}\right)
$$

Secondly, the producer considers the expected price $p_{i j}$ to be received from alternative markets. The price is decomposed into:

$$
p_{i j}=\bar{p}_{j} \pm B\left(q_{i}, z_{i}^{b}\right)
$$

where $\bar{p}_{j}$ is a market specific price and $B\left(q_{i}, z_{i}^{b}\right)$ is the potential price mark-up that the producer expects to receive. The mark-up depends on the quantity of mushrooms sold $q_{i}$ and other bargaining-related attributes such as product quality $z_{i}^{b}$. Finally, selling in market $j_{i}$ could also be associated with fixed transaction costs $T C^{f}\left(z_{i j}^{f}\right)$ that are invariable with the quantity sold and include costs like searching for potential buyers and obtaining information about prices, markets, or types of possible contractual arrangements.

Based on the above, and for a given transaction $i$, a producer chooses to sell $q_{i}$ in the $j_{i}$ market which yields the highest net profit among the $k=1, \ldots, j$ alternative markets. This can be expressed as:

$$
j_{i}=\max _{k}\left\{\Pi_{i k}=q_{i} \cdot\left[\left(\bar{p}_{i k} \pm B\left(q_{i}, z_{i}^{b}\right)-T C_{i k}^{p}\left(d_{i k}, m_{i k}, z_{i k}^{p}\right)\right]-T C^{f}\left(z_{i k}^{f}\right), k=1, \ldots, j\right\} .\right.
$$

So, assuming there are two alternative markets $\left(j_{1}\right.$ and $\left.j_{2}\right)$, a producer will choose to sell to $j_{1}$ if

$$
\begin{aligned}
& \left\{\Pi_{1 k}=q \cdot\left[\left(\bar{p}_{1 k} \pm B\left(q_{1}, z_{1}^{b}\right)-T C_{1 k}^{p}\left(d_{1 k}, m_{1 k}, z_{1 k}^{p}\right)\right]-T C^{f}\left(z_{1 k}^{f}\right)\right\}\right. \\
& \left\{\Pi_{2 k}=q \cdot\left[\left(\bar{p}_{2 k} \pm B\left(q_{2}, z_{2}^{b}\right)-T C_{2 k}^{p}\left(d_{2 k}, m_{2 k}, z_{2 k}^{p}\right)\right]-T C^{f}\left(z_{2 k}^{f}\right)\right\} .\right.
\end{aligned}
$$

However, he/she will sell to $j_{2}$ if $\Pi_{2 k}>\Pi_{1 k}$, and will be indifferent if $\Pi_{2 k}=\Pi_{1 k}$. The next subsection presents the empirical model. 


\subsection{Empirical model}

Upon realising some marketable surplus, producers usually make two types of decisions in relation to their marketing strategy. The first decision relates to the choice of marketing channel, and the second to the quantity of the produce to supply through the selected channel. With very few exceptions (e.g. Shiimi et al., 2012), most previous related studies (e.g. Hobbs, 1997; Gong et al., 2007; Woldie \& Nuppenau, 2011) have analysed the effects of transaction costs on these two choices using the Tobit model, implying that farmers make these decisions simultaneously. The broader inference of these studies is that farmers' supply of commodities is price inelastic, an attribute which entails that farmers are less likely to respond to changing market conditions, making them more susceptible to conditions set by buyers. Other researchers (e.g. Katchova \& Miranda, 2004), however, contend that such marketing decisions are made sequentially, suggesting that producers pay attention to market conditions, and with the information gathered, they first decide whether or not to participate in a particular channel prior to making the decision on the proportion of the commodity to sell through the selected channel. Sequential decisions are analysed using two-step approaches such as the Cragg's model, also known as the doublehurdle model (Green, 2003).

Within a simultaneous decision-making framework, the dependent variable is captured as the proportion of the commodity sold through the preferred channel. Given that producers who do not participate in this channel will record zero per cent of the commodity sold, the dependent variable becomes censored at a threshold of zero, necessitating the use of a Tobit model (Green, 2003). The principal underlying assumption of the Tobit is that the probability of channel choice also increases the average quantity of the commodity supplied; hence, the effect of a particular variable will be the same on the choice of marketing channel and proportion of quantity supplied (Burke, 2009). It is against such attributes of the Tobit that Cragg (1971) proposed the more flexible double-hurdle model, which allows the outcomes to be determined by separate stochastic processes. Following Green (2003), Cragg's model is specified as follows:
Channel choice equation

$\operatorname{Pr}\left[y_{i}^{*}>0\right]=\Phi\left(x_{i}^{\prime} \gamma\right), \quad z_{i}=1$ if $y_{i}^{*}>0$

$\operatorname{Pr}\left[y_{i}^{*} \leq 0\right]=1-\Phi\left(x_{i}^{\prime} \gamma\right), \quad z_{i}=0$ if $y_{i}^{*} \leq 0$

Quantity decision

$E\left[y_{i} \mid z_{i}=1\right]=x_{i}^{\prime} \beta+\sigma \lambda_{i}$

where $\gamma$ and $\beta$ are coefficients to be estimated, $y$ is the observed use of the preferred marketing channel, and $x$ represents the factors that are hypothesised to affect the producers' marketing behaviour. Cragg's model is a combination of the Probit in equation 5 (choice of marketing channel) and a Truncated regression model in equation 6 (quantity sold), which can be estimated independently. If $z_{i}=x_{i}$ and $\gamma=\beta / \sigma$, Cragg's model reduces to the Tobit model, causing the variables to influence the channel choice decision and quantity supplied in the same manner. In attempting to get an indication of whether marketing decisions by mushroom producers in Swaziland are made simultaneously or sequentially, a likelihood ratio (LR) test was conducted wherein the Tobit was tested against Cragg's model by respectively estimating the Tobit, Probit and Truncated regression using the same variables, and thereafter computing a likelihood ratio (LR) statistic as follows (Green, 2003):

$\lambda=-2\left[\ln L_{T}-\left(\ln L_{P}+\ln L_{T R}\right)\right]$

where $\ln L_{\mathrm{T}}=\log$ of the likelihood for the Tobit model; $\ln L_{\mathrm{P}}=\log$ of the likelihood for the Probit model; and $\ln L_{\mathrm{TR}}=\log$ of the likelihood for the Truncated regression model. $\lambda$ has a $\chi^{2}$ distribution with $\mathrm{R}(\mathrm{df})$, where $\mathrm{R}$ is the number of independent variables plus the constant. The Tobit model is rejected in favour of Cragg's model if $\lambda$ exceeds the appropriate $\chi^{2}$ critical value. The next sub-section presents the data collection procedures.

\subsection{Data collection}

The study relied on a data set obtained from a wide-ranging survey on mushroom production in Swaziland, where data were collected between December 2011 and January 2012. Using information gathered from the Mushroom Development Unit (MDU), producers as at December 2011 comprised of 11 farmer groups, whose respective members are located in more or less the same communities, and 74 
individuals found in various locations. Farmer groups operate in predominantly two models. In model A members produce mushrooms in one growing room and share all production and marketing activities. In model $\mathrm{B}$, members share all preparatory activities, including substrate gathering and spawning of bags. ${ }^{2}$ However, instead of producing under one roof, each member manages his/her own production house. Groups that operate using model B allow members to make their own marketing arrangements independently. Given that the adopted analytical model requires household explanatory variables, it was found reasonable to use data generated from individual producers and members affiliated to groups that operate using model B. Among the 11 groups, only two (Mbangweni and Zombodze) operate using model B. From a total of 38 members from Mbangweni and 25 from Zombodze, interviews were conducted with 36 members from Mbangweni and 24 from Zombodze, respectively. From the list of 74 registered individual producers, 43 owned production structures but had not started producing at the time the interviews were conducted. Therefore, 31 producers from this category were interviewed, bringing the number of respondents to 91 . The dependent and explanatory variables used in the analytical model are presented in the following section.

\subsection{Dependent and explanatory variables}

\subsubsection{Dependent variable}

Currently, no cultivated mushrooms are exported from Swaziland and producers have not yet engaged in any form of mushroom processing. Instead, from what they harvest, about six to ten per cent is consumed at household level and the remainder sold through four channels identified as: (i) the farm gate; (ii) retail market (supermarkets); (iii) middlemen; and (iv) food services industry (restaurants/hotels). This can be depicted as follows:

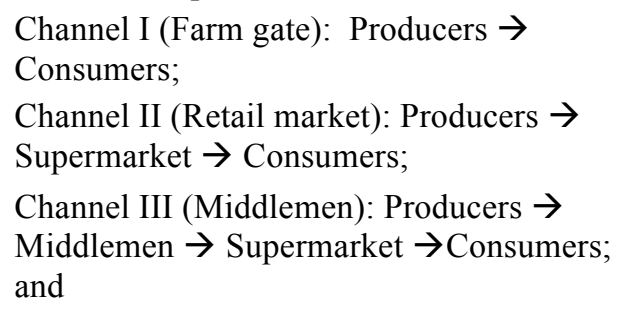

Channel IV (Food services industry):

Producers $\rightarrow$ Restaurant/hotel $\rightarrow$ Consumers.

About $528 \mathrm{~kg}$ of fresh oyster mushrooms were traded by the respondents between November 2011 and January 2012 through the identified channels. Further analysis indicated that 42 per cent of these mushrooms were sold at the farm gate, 52 per cent through the retail market, whereas 2 per cent and 4 per cent, respectively, were sold through middlemen and the food services industry. Some producers reported to have sold mushrooms through different channels, indicating that the options are not mutually exclusive. On account of these observations, and for ease of analysis, producers who sold to more than one outlet $\left(j_{1}, \ldots, j_{4}\right)$ were adjudged to prefer selling through $j_{1}$ if a greater proportion of their marketable surplus was sold through $j_{1}$ compared to what they sold to other $j$ outlets. Subsequent to the re-classification according to preference, two marketing channels were found prominent, and these were supermarkets (or retail outlets) used by 53 per cent of respondents and the farm gate used by 47 per cent. Considering the above observations, the dependent variable was formulated around the retail market option; hence, a value of one was assigned if the producer sold through the retail market channel and zero if the produce was sold at the farm gate. For the quantity model, the dependent variable was the proportion of mushrooms sold through the retail channel, ranging between 0 and 100 per cent.

\subsubsection{Explanatory variables}

Transaction cost variables were measured by ranking producers' responses to a list of questions related to the constraints they encounter in marketing their mushrooms. The set of questions were classified into three components, namely (i) information and search costs; (ii) negotiation, bargaining, and transfer costs; and (iii) monitoring and enforcement costs. The adopted measurement criterion works on the premise that transaction costs are assumed to be observable if, ceteris paribus, a particular type of transaction cost is higher in channel $\left(j_{1}\right)$ than in channel $\left(j_{2}\right)$, and different producers consistently specify the same ranking whenever the two situations are considered (Cheung, 1998). The explanatory variables are discussed below and summarised in Table 1. 
Table 1

Variables included in the regression model

\begin{tabular}{|c|c|c|c|}
\hline \multicolumn{4}{|c|}{ Dependant variables } \\
\hline Variable & Description & \multicolumn{2}{|l|}{ Measurement } \\
\hline $\begin{array}{l}\text { Marketing channel through which } \\
\text { mushrooms are sold }\end{array}$ & Selling at the farm gate or retail market? & \multicolumn{2}{|l|}{$1=$ retail market; $0=$ farm gate } \\
\hline Proportion of mushrooms sold & $\%$ of total mushrooms sold & \multicolumn{2}{|l|}{$0-100$} \\
\hline \multicolumn{4}{|c|}{ Household characteristics } \\
\hline Variable & Description & Measurement & $\begin{array}{l}\text { Expected } \\
\text { sign }\end{array}$ \\
\hline 1. Education level of producer & Category last attended & $\begin{array}{l}\text { 1= Illiterate; } 2=\text { Adult education; } \\
3=\text { Primary } 4=\text { Secondary; } \\
\text { 5= High school; } \\
6=\text { College } / \text { Vocational } \\
7=\text { University }\end{array}$ & + \\
\hline 2. Household labour endowment & Man-equivalents & $\begin{array}{l}\text { Less than } 9 \text { yrs }=0 ; 9-15=0.7 \\
16-49=1 ; \text { above } 49=0.7\end{array}$ & + \\
\hline \multicolumn{4}{|c|}{ Production } \\
\hline 3. Size of production & Spawn-impregnated bags ${ }^{a}$ & Number & + \\
\hline 4. Ownership of refrigerator & Does the household own a refrigerator? & $1=y e s ; 0=$ no & + \\
\hline 5. Group membership & $\begin{array}{l}\text { Is the producer a member of a mushroom } \\
\text { producing group? }\end{array}$ & $1=y e s ; 0=$ no & + \\
\hline \multicolumn{4}{|c|}{ Information and search costs } \\
\hline $\begin{array}{l}\text { 6. Knowledge of prices in } \\
\text { alternative markets }\end{array}$ & $\begin{array}{l}\text { Was the price in alternative markets } \\
\text { known before selling the mushrooms? }\end{array}$ & $1=$ yes; $0=$ no & $-/+$ \\
\hline $\begin{array}{l}\text { 7. Difficulty in accessing price } \\
\text { information }\end{array}$ & $\begin{array}{l}\text { How difficult is it to access price } \\
\text { information? }\end{array}$ & $\begin{array}{l}1=\text { not an issue of concern; } \\
2=\text { very easy; } 3=\text { easy; } 4=\text { difficult; } \\
5=\text { =very difficult }\end{array}$ & - \\
\hline \multicolumn{4}{|c|}{ Negotiation, bargaining and transfer costs } \\
\hline 8. Search for trading partner & $\begin{array}{l}\text { How difficult is it to locate exchange } \\
\text { partners/buyers? }\end{array}$ & $\begin{array}{l}1=\text { not an issue of concern; } \\
2=\text { very easy; } 3=\text { easy; } 4=\text { difficult; } \\
5=\text { =very difficult }\end{array}$ & - \\
\hline 9. Transportation difficulty & $\begin{array}{l}\text { How difficult is it to transport your } \\
\text { produce to the market? }\end{array}$ & $\begin{array}{l}1=\text { not an issue of concern; } \\
2=\text { very easy; } 3=\text { =easy; } 4=\text { difficult; } \\
5=\text { very difficult }\end{array}$ & - \\
\hline 10. Bargaining power & Who sets the exchange price? & $1=$ producer; $0=$ buyer or both & + \\
\hline \multicolumn{4}{|c|}{ Monitoring and enforcement costs } \\
\hline 11. Quality uncertainty & $\begin{array}{l}\text { Is there uncertainty that your mushrooms } \\
\text { will not meet the expected quality of } \\
\text { preferred buyer? }\end{array}$ & $1=y e s ; 0=$ no & - \\
\hline
\end{tabular}

Note: 'Spawn-impregnated bags' are substrate bags that have been inoculated with the mushroom seed, known as spawn (Gwanama et al., 2011).

\section{Information and search costs}

Prior to making any exchange, producers will, among other expectations, be required to establish who to sell their mushrooms to and the prices at which to sell them. By so doing, they will incur information costs whose magnitude depends on the time taken to conduct the search. Going into production without the knowledge of current prices in alternative markets creates some uncertainty in that despite making their own price expectations, producers will have no guarantee that they will eventually receive that price unless they know in advance which price the buyer will agree to buy at (Hobbs, 1997). Similar to Woldie and Nuppenau (2011), information cost due to such price uncertainty was measured by considering whether farmers knew the price in alternative markets ahead of transacting, while the search for price information and trading partner(s) were measured by taking into account the difficulty with which the two were accomplished, respectively. 
Negotiation, bargaining and transfer costs

Smallholder farmers are generally price takers and the level of transaction costs is likely to increase if they need to travel long distances to reach their point(s) of sale (Pingali, Khwaja \& Maijer, 2005). While transportation costs may not be considered by some researchers as a transaction cost component, the inclusion of transport-related variables in this study was meant to account for the opportunity cost of producers' time spent in organising transport to convey their mushrooms to distant markets. Farmers' bargaining position was considered as a measure of their influence on exchange agreements, particularly in setting of exchange prices. Gong et al. (2007) and Woldie and Nuppenau (2011) found that farmers who produce in bulk tend to enjoy relatively more bargaining power and are likely to influence buying terms. Therefore, it is expected that producers would be inclined to supply a greater proportion of their commodity through a channel where they have a better bargaining position.

\section{Monitoring and enforcement costs}

One of the key monitoring costs considered in the study is quality uncertainty. While there are currently no formal quality standards for traded mushrooms in Swaziland, supermarkets, the major buyers, generally screen delivered mushrooms for quality based on visual inspection for browning, weight loss and microbial spoilage. Producers' returns are likely to be lower than anticipated if mushrooms do not meet the buyers' expected quality standards. Mushrooms are highly perishable products and, as observed by Fraser (1995), if the producer faces some uncertainty about selling his/her mushrooms due to quality considerations, perishability could be of grave concern as he/she may either sell at a reduced price (due to shrinkage) or not sell at all due to advanced spoilage. The inclusion of this variable was based on evidence provided by Hobbs (1997) and Gong et al. (2007) who found that high levels of quality uncertainty are more likely to result in producers selling their mushrooms through a channel with no stringent quality requirements. No variable was included in the model to capture enforcement costs as none of the farmers had valid contracts of any form with their buyers, except verbal agreements for those supplying retail outlets. Furthermore, no conflicts were reported that perhaps warranted follow-up visits or calls from producers as a result of delayed or defaulted payments.

\section{Household and production attributes}

While it is generally believed that transaction costs reflect the character of the market, others (e.g. Pingali et al., 2005) posit that transaction costs are mainly entrenched in the characteristics of individual households and the environment they live in. In particular, Pingali et al. (2005) argue that the time taken to search, process and act on market information decreases with better education. Others (e.g. Fafchamps \& Hill, 2005) have established that farmers who produce in large quantities are more likely to travel to the market in search for relatively higher exchange prices. These two factors were respectively analysed by considering producers' level of education, and the number of spawn-impregnated bags they manage. Given the perishability of mushrooms and the amount of work required in the enterprise, it was found prudent to include other variables to account for ownership of cooling facilities (refrigerators) and household labour endowment, respectively. Considering members who were identified to participate in household agricultural activities, household labour endowment was measured following Langyintuo and Mungoma (2008) in man-equivalents. The identified members include even school-attending children who also participate in household agricultural activities, especially outside school-attending hours including weekends and holidays.

The following section presents the study's empirical results. It begins with an overview of the descriptive statistics of variables used in the analytical model, followed by a discussion of the significant factors affecting producers' channel choice decisions and quantity supplied.

\section{3}

\section{Results and discussions}

\subsection{Descriptive statistics of variables used in the analytical model}

The descriptive statistics are summarised in Table 2 below. 
Table 2

Descriptive statistics of variables used in the regression model

\begin{tabular}{|c|c|c|c|c|c|c|}
\hline \multicolumn{7}{|c|}{ Categorical variables } \\
\hline \multicolumn{2}{|c|}{$\begin{array}{c}{[\mathrm{A}]} \\
\text { Variable }\end{array}$} & $\begin{array}{l}{[\mathrm{B}]} \\
\text { Unit }\end{array}$ & $\begin{array}{c}{[\mathrm{C}]} \\
\% \text { of total } \\
\text { respondents } \\
(\mathrm{N}=91)\end{array}$ & $\begin{array}{c}{[D]} \\
\% \text { of }[\mathrm{C}] \text { from } \\
\text { retail } \\
(\mathrm{N}=48)\end{array}$ & $\begin{array}{c}{[E]} \\
\% \text { of }[\mathrm{C}] \text { from } \\
\text { farm gate } \\
(\mathrm{N}=43)\end{array}$ & $\begin{array}{c}{[\mathrm{F}]} \\
x^{2} \text {-value }\end{array}$ \\
\hline \multirow{2}{*}{\multicolumn{2}{|c|}{ Gender of producer }} & Female & 74.7 & 55.9 & 44.1 & \multirow[t]{2}{*}{1.061} \\
\hline & & Male & 25.3 & 43.5 & 56.5 & \\
\hline \multirow{2}{*}{\multicolumn{2}{|c|}{ Membership in mushroom producing group }} & Member & 65.9 & 53.3 & 46.7 & \multirow[t]{2}{*}{0.024} \\
\hline & & Non- member & 34.1 & 51.6 & 48.4 & \\
\hline \multirow{2}{*}{\multicolumn{2}{|c|}{ Ownership of refrigerator }} & Yes & 58.2 & 64.2 & 35.8 & \multirow[t]{2}{*}{$6.622^{-\mathrm{knm}}$} \\
\hline & & No & 41.8 & 36.8 & 63.2 & \\
\hline \multirow{2}{*}{\multicolumn{2}{|c|}{$\begin{array}{l}\text { Knowledge of producer price in alternative } \\
\text { markets }\end{array}$}} & Yes & 37.4 & 55.9 & 44.1 & \multirow[t]{2}{*}{1.622} \\
\hline & & No & 62.6 & 42.1 & 57.9 & \\
\hline \multirow{2}{*}{\multicolumn{2}{|c|}{$\begin{array}{l}\text { Bargaining power (who sets the producer } \\
\text { price?) }\end{array}$}} & Producer & 64.8 & 28.8 & 71.2 & \multirow[t]{2}{*}{$38.560^{\mathrm{nkm}}$} \\
\hline & & Buyer or both & 35.2 & 96.9 & 3.1 & \\
\hline \multirow{2}{*}{\multicolumn{2}{|c|}{ Quality uncertainty }} & Yes & 36.3 & 75.8 & 24.2 & \multirow[t]{2}{*}{$10.999^{\mathrm{mm}}$} \\
\hline & & No & 63.7 & 39.7 & 60.3 & \\
\hline \multirow[t]{4}{*}{ Type of transport used ${ }^{b}$} & Own vehicle & Percentage & 13.2 & 91.7 & 8.3 & \multirow[t]{4}{*}{$63.705^{n \pi}$} \\
\hline & Public transport & Percentage & 48.4 & 84.1 & 15.9 & \\
\hline & By foot & Percentage & 11 & 0 & 100 & \\
\hline & No need to travel & Percentage & 27.5 & 0 & 100 & \\
\hline \multicolumn{7}{|c|}{ Continuous variables } \\
\hline \multicolumn{2}{|c|}{ Variable } & Unit & $\begin{array}{l}\text { Mean of total } \\
\text { respondents } \\
(\mathrm{N}=91)\end{array}$ & $\begin{array}{l}\text { Mean } \\
\text { retail } \\
(\mathrm{N}=48)\end{array}$ & $\begin{array}{c}\text { Mean } \\
\text { farm gate } \\
(\mathrm{N}=43)\end{array}$ & t-value \\
\hline \multicolumn{2}{|l|}{ Age of producer } & Years & 50 & 50 & 49 & -0.588 \\
\hline \multicolumn{2}{|l|}{ Labour endowment } & Man-equiv. $^{\dagger}$ & 4.8 & 4.6 & 4.8 & -0.356 \\
\hline \multicolumn{2}{|c|}{ Number of spawn-impregnated bags } & Bags & 502 & 401 & 581 & $-2.462^{* x}$ \\
\hline \multicolumn{2}{|l|}{ Producer price $^{b}$} & $\mathrm{E} / \mathrm{kg}^{3}$ & & 51.80 & 41.00 & $-3.505^{\mathrm{km}}$ \\
\hline \multicolumn{7}{|c|}{ Ordered variables } \\
\hline \multicolumn{2}{|c|}{ Variable } & Unit & $\begin{array}{l}\text { Mode of total } \\
\text { respondents } \\
\quad(\mathrm{N}=91)\end{array}$ & $\begin{array}{l}\text { Mode } \\
\text { retail } \\
(\mathrm{N}=48)\end{array}$ & $\begin{array}{c}\text { Mode } \\
\text { farm gate } \\
(\mathrm{N}=43)\end{array}$ & $x^{2}$-value \\
\hline \multicolumn{2}{|c|}{ Difficulty in accessing price information } & Modal score ${ }^{\dagger}$ & 3 & 4 & 3 & $14.500^{\mathrm{kx*}}$ \\
\hline \multicolumn{2}{|c|}{ Difficulty in locating trading partner } & Modal score $^{\dagger}$ & 3 & 3 & 3 & 5.931 \\
\hline \multicolumn{2}{|c|}{ Difficulty in accessing transport } & Modal score $^{\dagger}$ & 1 & 1 & 1 & 5.032 \\
\hline \multicolumn{2}{|l|}{ Producer's education level } & Modal score $^{\dagger}$ & 4 & 4 & 3 & $12.144^{* *}$ \\
\hline \multicolumn{2}{|l|}{ Distance to market ${ }^{b}$} & Modal score & 0 & 7 & 0 & $79.021^{x \times x}$ \\
\hline
\end{tabular}

Source: Survey data (2011/12)

Notes:

${ }^{b}$ indicates variables not included in the regression model

${ }^{\dagger}$ Refer to Table 1 for measurement of variables

- $0=$ no need to travel; $1=l$ ess than $1 \mathrm{~km} ; 2=1-2 \mathrm{~km} ; 3=2.1-3 \mathrm{~km} ; 4=3.1-4 ; 5=4.1-5 ; 6=5.1-10 \mathrm{~km} ; 7=a b o v e 10 \mathrm{~km}$

", and "** represent $10 \%, 5 \%$, and $1 \%$ levels of significance, respectively.

The average age of interviewed producers was 50 years, and the majority ( 75 per cent) were women. Almost 58 per cent owned refrigerators, of whom 36 per cent sold at the farm gate, while the rest supplied the retail market. The producers had a relatively low level of education as slightly over 65 per cent did not go beyond secondary school. About 63 per cent indicated that they did not have access to price information in alternative markets and 58 per cent of producers in this category sold their mushrooms at the farm gate. Of the 65 per cent who indicated to be selling at prices set by themselves, 71 per cent sold at the farm gate, while the remainder used either their own vehicles or public transport to convey mushrooms to the nearest retail outlets. Producers who sold at the farm gate had lower uncertainty 
about the quality of their mushrooms which they sold at relatively lower producer prices. Due to poor customer turnout in some areas, only 11 per cent indicated occasionally walking around the neighbourhood in search of buyers as a means to avoid losses resulting from spoilage. Farmers who were more inclined to sell to the retail market are those who produced relatively more in terms of the number of spawn-impregnated bags they managed. About 66 per cent of the producers were affiliated to mushroom producing groups, of whom 53 per cent preferred the retail market to the farm gate.

\subsection{Factors affecting channel choice and quantity supplied}

Having detected no significant multicollinearity among the explanatory variables, the regression models were estimated using Stata11, and the results are presented in Table 3. With a likelihood ratio (LR) of 99.63 at $12 \mathrm{df}(p<0.01)$, the Tobit model was rejected in favour of Cragg's model, suggesting that mushroom producers are more likely to make their marketing decisions of channel choice and quantity supplied sequentially. ${ }^{4}$

Consistent with Fafchamps and Hill's (2005) findings, the results indicate that farmers who produced relatively more (in terms of the number of spawn-impregnated bags) had a high likelihood of selling their mushrooms to the retail market. Producers' quest to supply the retail market was also enhanced by ownership of refrigerators which allowed them to store the mushrooms for a couple of days before transporting them. One of the unique attributes of oyster mushrooms is that although the harvested quantities decline over time, from the first flush they can be harvested continuously for a period of about three to four months, subject to prevailing conditions (Gwanama et al., 2011). Therefore, the advantage of owning a refrigerator is that a producer may harvest for a couple of days, store and thereafter make a single trip to the market. As indicated earlier, the mushroom enterprise is labour-demanding in almost all production, harvesting and post-harvest handling procedures. It is not surprising, therefore, that high labour endowment enabled the household to produce and market relatively larger quantities, which they were able to transport to the retail market.
The results also indicate that producers who were unaware of prevailing prices in alternative markets and had difficulty in accessing price information were more likely to sell their mushrooms at the farm gate. The negative, significant coefficient for bargaining power confirmed Woldie and Nuppenau's (2011) persuasion that the paucity of market information denies producers the leverage to bargain for exchange prices; hence, prices and exchange terms were dictated by the buyers. As a result, producers who could not bargain at the retail market were more inclined to sell their mushrooms at the farm gate. Despite being price takers and often required to travel, farmers who sold their produce to retail outlets were presumably attracted by market reliability and a comparatively high producer price. Another important observation from the results is that producers who were affiliated to mushroom producing groups were more likely to sell to the retail market. While these producers did not sell collectively, it could be inferred that performing certain tasks as a group builds some social cohesion, which enables them to share information beyond the joint activities. In any group setting characterised by mutual trust between members, there are possibilities for sharing skills and information as some members could be more experienced and knowledgeable than others.

Only two factors were found to significantly influence the quantity of mushrooms sold. The first relates to the difficulty encountered in organising transport, which significantly influenced farmers to sell their mushrooms at the farm gate. As noted earlier, producers who supply the retail market are required to travel, whereas a majority of those who sell at the farm gate rarely transport their mushrooms as buyers generally consist of locally-based community members. Accessing the retail market comes with an opportunity cost of time spent in organising transport and time spent during transportation. Given that most producers relied on public transport to convey their mushrooms to the market, it is evident that they had no control on regulating transportation periods. The second factor relates to producers' quality uncertainty. Contrary to previous findings (e.g. Hobbs, 1997 and Gong et al., 2007), the coefficient for quality uncertainty 
was positively related to the quantity of mushrooms sold through the retail market. Generally, it would be expected that the more producers become concerned about meeting buyers' quality requirements, the less of mushrooms they will supply to that particular channel. However, as observed by Staal et al. (1997), it could be inferred that while producers were often uncertain about whether their mushrooms would meet the buyers' expectations for quality, the market reliability and comparatively better exchange price offered by the retail market seemed to outweigh the uncertainty about quality such that producers were willing to increase their supply in order to avoid the farm gate option, which relies mostly on unpredictable consumer turnout.

\section{Table 3}

Regression results for factors influencing choice of marketing channel and proportion of mushrooms sold by producers in Swaziland

\begin{tabular}{|c|c|c|c|c|c|c|c|c|c|}
\hline \multirow{3}{*}{ Explanatory variables } & \multicolumn{3}{|c|}{ Tobit } & \multicolumn{3}{|c|}{ Probit } & \multicolumn{3}{|c|}{ Truncated regression } \\
\hline & \multirow[b]{2}{*}{$\beta$} & \multicolumn{2}{|c|}{ Marginal effects } & \multirow[b]{2}{*}{$\beta$} & \multicolumn{2}{|c|}{ Marginal effects } & \multirow[b]{2}{*}{$\beta$} & \multicolumn{2}{|c|}{ Marginal effects } \\
\hline & & $\partial y / \partial x$ & $\begin{array}{c}z- \\
\text { value }\end{array}$ & & $\partial y / \partial x$ & $\begin{array}{c}z- \\
\text { value }\end{array}$ & & $\partial y / \partial x$ & $\begin{array}{c}\text { z- } \\
\text { value }\end{array}$ \\
\hline Constant & $\begin{array}{l}-63.560 \\
(49.370)\end{array}$ & & & $\begin{array}{l}-1.031 \\
(1.460)\end{array}$ & & & $\begin{array}{l}64.067 \times * \\
(17.535)\end{array}$ & & \\
\hline Producer's education level & $\begin{array}{l}14.256 " \\
(5.889)\end{array}$ & $\begin{array}{l}8.252^{\mathrm{x}} \\
(3.423)\end{array}$ & 2.41 & $\begin{array}{c}0.255 \\
(0.177)\end{array}$ & $\begin{array}{l}0.088 \\
(0.061)\end{array}$ & 1.44 & $\begin{array}{c}3.772 \\
(2.920)\end{array}$ & $\begin{array}{l}3.344 \\
(2.666)\end{array}$ & 1.250 \\
\hline Labour endowment & $\begin{array}{l}2.388 \\
(2.867)\end{array}$ & $\begin{array}{c}1.382 \\
(1.663)\end{array}$ & 0.83 & $\begin{array}{l}0.194 \\
(0.093)\end{array}$ & $\begin{array}{l}0.067^{m *} \\
(0.032)\end{array}$ & 2.07 & $\begin{array}{c}0.135 \\
(1.367)\end{array}$ & $\begin{array}{c}0.120 \\
(1.214)\end{array}$ & 0.100 \\
\hline $\begin{array}{l}\text { Number of spawn- } \\
\text { impregnated bags }\end{array}$ & $\begin{array}{l}0.066 \times \\
(0.022)\end{array}$ & $\begin{array}{l}0.038 \\
(0.013)\end{array}$ & 2.90 & $\begin{array}{l}0.003^{\cdots \cdots} \\
(0.001)\end{array}$ & $\begin{array}{l}0.001 \\
(0.000)\end{array}$ & 2.98 & $\begin{array}{c}0.018 \\
(0.013)\end{array}$ & $\begin{array}{l}0.016 \\
(0.012)\end{array}$ & 1.390 \\
\hline Ownership of refrigerator & $\begin{array}{l}29.167 \\
(14.800)\end{array}$ & $\begin{array}{l}16.376 \\
(7.533)\end{array}$ & 2.17 & $\begin{array}{l}1.426 \\
(0.405)\end{array}$ & $\begin{array}{l}0.487 \\
(0.128)\end{array}$ & 3.80 & $\begin{array}{l}-0.444 \\
(6.293)\end{array}$ & $\begin{array}{l}-0.393 \\
(5.573)\end{array}$ & -0.070 \\
\hline $\begin{array}{l}\text { Knowledge of prices in } \\
\text { alternative markets }\end{array}$ & $\begin{array}{l}-12.331 \\
(14.549)\end{array}$ & $\begin{array}{l}-7.021 \\
(8.106)\end{array}$ & -0.87 & $\begin{array}{l}-0.903^{\mathrm{x}} \\
(0.435)\end{array}$ & $\begin{array}{l}-0.321^{n \star} \\
(0.152)\end{array}$ & -2.10 & $\begin{array}{c}6.622 \\
(6.955)\end{array}$ & $\begin{array}{c}5.754 \\
(5.851)\end{array}$ & 0.980 \\
\hline $\begin{array}{l}\text { Difficulty in accessing price } \\
\text { information }\end{array}$ & $\begin{array}{r}-11.665 \\
(6.829) \\
\end{array}$ & $\begin{array}{l}-6.753 \\
(3.928)\end{array}$ & -1.72 & $\begin{array}{l}-0.488 \\
(0.290)\end{array}$ & $\begin{array}{l}-0.168 \\
(0.105)\end{array}$ & -1.60 & $\begin{array}{l}-1.152 \\
(3.217)\end{array}$ & $\begin{array}{l}-1.022 \\
(2.854)\end{array}$ & -0.360 \\
\hline $\begin{array}{l}\text { Difficulty in locating trading } \\
\text { partner }\end{array}$ & $\begin{array}{c}7.842 \\
(6.463)\end{array}$ & $\begin{array}{c}4.540 \\
(3.639)\end{array}$ & 1.25 & $\begin{array}{c}0.156 \\
(0.198)\end{array}$ & $\begin{array}{c}0.054 \\
(0.070)\end{array}$ & 0.77 & $\begin{array}{l}-3.562 \\
(2.892)\end{array}$ & $\begin{array}{l}-3.158 \\
(2.579)\end{array}$ & -1.220 \\
\hline $\begin{array}{l}\text { Difficulty in accessing } \\
\text { transport }\end{array}$ & $\begin{array}{l}-5.550 \\
(5.377)\end{array}$ & $\begin{array}{l}-3.213 \\
(3.157)\end{array}$ & -1.02 & $\begin{array}{l}-0.175 \\
(0.170)\end{array}$ & $\begin{array}{l}-0.061 \\
(0.058)\end{array}$ & -1.05 & $\begin{array}{l}-5.246^{\pi \times} \\
(2.526)\end{array}$ & $\begin{array}{l}-4.651^{x *} \\
(2.213)\end{array}$ & -2.100 \\
\hline Bargaining power & $\begin{array}{l}-77.578^{* \cdots *} \\
(15.887)\end{array}$ & $\begin{array}{l}-46.357^{* \cdots *} \\
(8.6112) \\
\end{array}$ & -5.38 & $\begin{array}{c}-3.584 \times \\
(0.653)\end{array}$ & $\begin{array}{l}-0.763^{x+\cdots} \\
(0.070)\end{array}$ & -10.91 & $\begin{array}{l}-4.647 \\
(6.313) \\
\end{array}$ & $\begin{array}{l}-4.148 \\
(5.749) \\
\end{array}$ & -0.720 \\
\hline Group membership & $\begin{array}{l}56.247^{\mathrm{nam}} \\
(16.795)\end{array}$ & $\begin{array}{l}28.961 \\
(7.008)\end{array}$ & 4.13 & $\begin{array}{l}2.285^{k \cdots} \\
(0.675)\end{array}$ & $\begin{array}{l}0.740 \\
(0.151)\end{array}$ & 4.91 & $\begin{array}{l}-9.115 \\
(9.561)\end{array}$ & $\begin{array}{l}-7.905 \\
(7.847)\end{array}$ & -1.010 \\
\hline Quality uncertainty & $\begin{array}{c}6.942 \\
(16.392)\end{array}$ & $\begin{array}{c}4.054 \\
(9.594)\end{array}$ & 0.42 & $\begin{array}{l}-0.133 \\
(0.438)\end{array}$ & $\begin{array}{l}-0.046 \\
(0.153)\end{array}$ & -0.30 & $\begin{array}{l}13.428^{*} \\
(7.267)\end{array}$ & $\begin{array}{l}11.833^{*} \\
(6.385)\end{array}$ & 1.850 \\
\hline sigma & $\begin{array}{l}50.157 \\
(6.623) \\
\end{array}$ & & & & & & $\begin{array}{l}16.280 \\
(2.234) \\
\end{array}$ & & \\
\hline Number of observations & 91 & & & 91 & & & 38 & & \\
\hline Log likelihood & -231.544 & & & -26.85 & & & -154.881 & & \\
\hline F-stat. & $5.62^{x * m}$ & & & & & & & & \\
\hline Prob. F-test & $p<0.01$ & & & & & & & & \\
\hline Pseudo $R^{2}$ & 0.130 & & & 0.573 & & & & & \\
\hline Wald $X^{2}$ (11df) & & & & $47.09^{\mathrm{Na*}}$ & & & $25.06^{\mathrm{kN*}}$ & & \\
\hline Prob. $x^{2}$ for Wald test & & & & $p<0.01$ & & & $p<0.01$ & & \\
\hline Correct classification & & & & $84.6 \%$ & & & & & \\
\hline $\begin{array}{l}\text { LR test for Tobit vs Cragg's } \\
\text { model }(\lambda)\end{array}$ & & & & & & & $99.63^{\mathrm{nN}}$ & & \\
\hline Prob. $x^{2}$ for LR test & & & & & & & $p<0.01$ & & \\
\hline
\end{tabular}

Source: Survey data (2011/12)

Notes: "," and "** represent 10\%, 5\%, and 1\% levels of significance, respectively. Figures in brackets are robust standard errors. 
4

\section{Conclusions and policy recommendations}

The study sought to analyse the effects of transaction costs on the choice of marketing channels and quantity of mushrooms sold by producers in Swaziland. Having used Cragg's model for analysis, the research indicates that the difficulty in accessing market information and lack of bargaining power reduces producers' likelihood of participating in remunerative markets. Given that retail outlets are located some distance away from farmers' production sites, those willing to take advantage of comparatively better producer prices and relatively stable market conditions have to incur transportation costs. Hence, the difficulty encountered in accessing transport is likely to reduce the amount of mushrooms supplied to the retail market. The study also highlights the importance of a Market Information System (MIS), which Swaziland is yet to establish despite numerous discussions that have taken several decades to conclude. Besides improving market transparency, full and easy access to reliable and up-to-date market information would strengthen producers' bargaining position and competitiveness as they would be able to make timely and better informed production and marketing decisions. Furthermore, in the absence of a prescribed quality management system for traded mushrooms, producers are subjected to having their mushrooms bought at lower prices or even rejected without informed justifications. This calls for the government to work with buyers in formulating harmonised measurable quality standards for the benefit of all value chain actors. These standards should be in line with existing international ones in order to facilitate mushroom trade with other countries.

With the current lack of coordination in mushroom marketing, major buyers are not spared from encountering transaction costs, given the small-scale exchanges they engage in with individual producers. However, changes that could allow the same volume of business to be concentrated in a smaller number of relatively larger and more secure transactions would benefit buyers and producers alike. This can be made possible by promoting collective marketing through the existing farmer groups. Collective marketing would also enable producers to strengthen their bargaining position and share costs related to the search for buyers, monitoring transactions and transportation of mushrooms to distant markets. In view of the sparse distribution of producers, supply chain management could be improved by establishing collection centres (fitted with cooling facilities) in strategic areas where buyers would procure the mushrooms in bulk. This investment could be funded by the government as part of its public mandate towards agricultural and rural development.

\section{Endnotes}

1 Substrate material refers to any substance on which mushrooms will grow. The substrate is to mushrooms what soil is to plants.

2 Oyster mushrooms are grown from polyethylene bags filled with substrate material. The mushroom 'seed' is known as spawn; hence, spawning is an equivalent of planting seeds in crop production.

3 'E' denotes Emalangeni, the Swaziland currency. E1 = US\$ 0.101 on 30 ${ }^{\text {th }}$ May 2013 (Central Bank of Swaziland, 2013).

4 Even though this conclusion emanates from empirical estimation, it is important to acknowledge that the analysis was conducted using data gathered from a relatively small number of respondents $(\mathrm{N}=91)$, an attribute considered as the study's main limitation. Worth highlighting, nonetheless, is that unlike in other SSA countries, mushroom production is a relatively new and non-conventional agricultural enterprise in Swaziland; hence, very few farmers currently participate in the industry (see Mabuza, Ortmann \& Wale, 2012, for details).

\section{Acknowledgments}

The authors thank the respondents for their participation and the Council for the Development of Social Science Research in Africa (CODESRIA) for funding the research (Grant SGRT.29T11). Additional financial support from the National Research Foundation (NRF) of South Africa (Grant IFR2011041400080) is also gratefully acknowledged. The authors take full ownership of opinions, findings, conclusions and recommendations, and absolve CODESRIA and NRF from any responsibility arising from this study. Two anonymous referees are also acknowledged for their informative comments on an earlier draft of the article. 


\section{References}

BURKE, W.J. 2009. Fitting and interpreting Cragg's Tobit alternative using Stata. The Stata Journal, 9(4):584-592.

CENTRAL BANK OF SWAZILAND. 2013. Currency rates. Available at: http://www.centralbank.org.sz/ [accessed 2013-05-30].

CHANG, S.T. \& MILES, P.G. 2004. Mushrooms: cultivation, nutrition value, medicinal effect, and environmental impact $\left(2^{\text {nd }}\right.$ ed.) Florida, USA: CRC Press.

CHEUNG, S.N.S. 1998. The transaction costs paradigm. Economic Inquiry, 36(4):514-521.

COASE, R.H. 1937. The nature of the firm. Economica, 4(16):386-405.

COLLINS, B.M. \& FABOZZI, F.J. 1991. A methodology for measuring transaction costs. Financial Analysts Journal, 47(2):27-36.

CRAGG, J.G.1971. Some statistical models for limited dependent variables with application to the demand for durable goods. Econometrica, 39(5):829-844.

DE JANVRY, A., FAFCHAMPS, M. \& SADOULET, E. 1991. Peasant household behavior with missing markets: Some paradoxes explained. Economic Journal, 101(409):1400-1417.

DELGADO, C.L. 1999. Sources of growth in smallholder agriculture in sub-Saharan Africa: the role of vertical integration of smallholders with processors and marketers of high value-added items. Agrekon, 38(Special issue):165-189.

EMONGOR, R. \& KIRSTEN, J. 2009. The impact of South African supermarkets on agricultural development in the SADC: a case study in Zambia, Namibia and Botswana. Agrekon, 48(1):60-84.

FAFCHAMPS, M. 2004. Market institutions in sub-Saharan Africa: theory and evidence. Cambridge, UK: The MIT Press.

FAFCHAMPS, M. \& HILL, R.V. 2005. Selling at the farm gate or travelling to market. American Journal of Agricultural Economics, 87(3):717-734.

FOOD AND AGRICULTURAL ORGANISATION (FAO). 2011. Swaziland Agricultural Development Programme (SADP), Mid-term evaluation final report. Office of Evaluation, FAO, Rome.

FRASER, R. 1995. An analysis of the role of uncertainty in the marketing of perishable products. Journal of Agricultural Economics, 46(2):233-240.

GABRE-MADHIN, E.Z. 2001. Market institutions, transaction costs and social capital in the Ethiopian grain market. Research Report 124, International Food Policy Research Institute, Washington D.C.

GOETZ, S.J. 1992. A selectivity model of household food marketing behaviour is sub-Saharan Africa. American Journal of Agricultural Economics, 74(2):444-452.

GONG, W., PARTON, K., COX, R.J. \& ZHOU, Z. 2007. Transaction costs and cattle farmers' choice of marketing channels in China. Management Research News, 30(1):47-56.

GREEN, W.H. 2003. Econometric Analysis ( $5^{\text {th }}$ ed.) New Jersey: Prentice Hall.

GWANAMA, C., MWALE, V.M. \& NSIBANDE, B. 2011. Basic procedures for small-scale production of oyster mushrooms. Windhoek: University of Namibia.

HOBBS, J.E. 1997. Measuring the importance of transaction costs in cattle marketing. American Journal of Agricultural Economics, 79(4):1082-1095.

HOBBS, J.E. \& KERR, W. 1999. Transaction costs. In: Bhagwan D.S. (ed.) The current state of economic science, Vol. 4, Rohtak: Spellbound Publications:2111-2133.

JAFFEE, S. 1995. Transaction costs, risks and the organisation of private sector food commodity systems. In: Jaffee, S. \& Morton, J. (eds.) Marketing Africa's High-Value Foods, Iowa, USA: Kendall/Hunt Publishing Company:21-62.

JAGWE, J.N. \& MACHETE, C. 2011. Effects of transaction costs on choice of selling point: a case of smallholder banana growers in the Great Lakes region of Central Africa. Agrekon, 50(3):109-123.

KARAAN, A.S.M. 1999. Bridging the small-big divide: a transaction cost approach to enterprise modelling for mussel mariculture in Saldanha Bay. Agrekon, 38(4):680-691.

KATCHOVA, A.L. \& MIRANDA, M.J. 2004. Two-step econometric estimation of farm characteristics affecting marketing contract decisions. American Journal of Agricultural Economics, 86(1):88-102. 
KEY, N., SADOULET, E. \& de JANVRY, A. 2000. Transaction costs and agricultural household supply response. American Journal of Agricultural Economics, 82(1):245-59.

KUMAR, P., KUMAR, A., PARAPPURATHU, S \& RAJU, S.S. 2011. Estimation of demand elasticity for food commodities in India. Agricultural Economics Research Review, 24(January-June):1-14.

LANGYINTUO, A.S. \& MUNGOMA, C. 2008. The effect of household wealth on the adoption of improved maize varieties in Zambia. Food Policy, 33(6):550-559.

MABUZA, M.L., ORTMANN, G.F. \& WALE, E. 2012. Determinants of farmers' participation in oyster mushroom production in Swaziland: implications for promoting a non-conventional agricultural enterprise. Agrekon, 51(4):19-40.

PINGALI, P., KHWAJA, Y. \& MAIJER, M. 2005. Commercialising small farms: reducing transaction costs. ESA Working paper No. 05-08, Agricultural and Development Economics Division, FAO, Rome.

ROUPAS, P., KEOGH, J., NOAKES, M., MARGETTS, C. \& TAYLOR, P. 2012. The role of edible mushrooms in health: Evaluation of the evidence. Journal of Functional Foods, 4(4):687-709.

ROYER, A. 2011. Transaction costs in milk marketing: a comparison between Canada and Great Britain. Agricultural Economics, 42(2):171-182.

SHIIMI, T., TALJAARD, P.R. \& JORDAAN, H. 2012. Transaction costs and cattle farmers' choice of marketing channel in North-Central Namibia. Agrekon, 51(1):42-58.

STAAL, S., DELGADO, C. \& NICHOLSON, C. 1997. Smallholder dairying under transaction costs in East Africa. World Development, 25(5):779-794.

VAKIS, R., SADOULET, E. \& de JANVRY, A. 2003. Measuring transaction costs from observed behaviour: Market choices in Peru. Working Paper, Department of Agricultural and Resource Economics, University of California Berkeley, USA.

WOLDI, G.A. \& NUPPENAU, E.A. 2011. A contribution to transaction costs: evidence from banana markets in Ethiopia. Agribusiness, 27(4):493-508.

ZERO EMISSIONS RESEARCH INITIATIVE (ZERI). 2005. ZERI Regional project for Africa. Annual Report for 2005. Available at: www.unam.na/centres/zeri/zeri_annualreport2005.doc [accessed 2012-11-07]. 